\title{
A Landscape-Level Assessment of Composition, Structural Heterogeneity and Distribution Pattern of Trees in Temperate Forest of Kashmir Himalaya, India
}

\section{ASHAQ AHMAD DAR}

Pondicherry University https://orcid.org/0000-0002-7508-438X

Narayanaswamy Parthasarathy ( $\nabla$ nparthasarathypu@gmail.com )

Pondicherry University

\section{Research}

Keywords: Kashmir Himalaya, Environmental drivers, Canonical Correspondence Analysis (CCA), Tree species distribution, Structural heterogeneity

Posted Date: January 16th, 2021

DOI: https://doi.org/10.21203/rs.3.rs-143011/v1

License: (1) (1) This work is licensed under a Creative Commons Attribution 4.0 International License. Read Full License 


\section{Abstract}

Background: A landscape-level quantitative assessment of tree species was conducted across three forest types viz., low-level blue pine (BP), mixed conifer (MC) and subalpine (SA) forests of Kashmir Himalaya, India to ascertain patterns of species composition, and stand structure heterogeneity. We performed analyses of tree composition and structural heterogeneity, and multivariate ordination for the distribution of species across the landscape.

Results: In total, thirteen tree species ranging from five in SA forest to ten species in MC forest were recorded. There was an overall forest compositional dissimilarity among the forest types. Pinus wallichiana and Abies pindrow were exclusive dominants under BP and SA forests, respectively, whereas, Abies pindrow and Pinus wallichaiana prevailed in sampled plots from mid-elevation $\mathrm{MC}$ forest. Pinaceae family contributing more than 98\% individual stems was the most speciose and dominant, followed by Sapindaceae (0.52\%) and Betulaceae (0.44\%). Stand density, basal area, as well as mean DBH differed among the forest types with an overall positive response to elevation. Besides $\mathrm{MC}$ forest, the diameter class distribution of BP and SA forests displayed characteristics 'reverse J-shaped' pattern, concluding its degenerated forest structure. Abies pindrow and Pinus wallichiana across the forests showed bell-shaped tree size distribution, indicated sporadic recruitment and/or due to targeting specific size classes. A single cluster in SA forest and two sub-clusters in BP and MC forests were displayed in abundance and species-based Bray-Curtis cluster analysis. Topographical factors, elevation and slope, were identified as the principal factors of tree species distribution patterns and positively correlated with Canonical Correspondence Analysis 1 (CCA1) and CCA2, respectively.

Conclusions: The quantitative landscape-level inventory of diversity across forest types indicated an overall less heterogenous tree composition with structural heterogeneity. CCA predicted elevation and slope as principal drivers determining species distribution. Information about these forest attributes are expected to provide better ecological insights and prospects for sustainable forest management and utilisation, and improving conservation strategies and ecosystem services.

\section{Background}

Topographical complexity across ecosystems contributes significantly to ecological diversity (Badgley et al., 2017 ). Mountain habitats reported to cover about $12 \%$ of the total earth's surface, contribute approximately $25 \%$ of the global species diversity and are rich in endemic species (Barthlott et al., 2005; Spehn et al., 2006). In fact, half of the global 36 hotspots and more than $33 \%$ of the terrestrial species diversity are in mountain systems (Körner, 2005). Continuous variations in elevation, terrain and related environmental factors are critical attributes of the mountain system. These features directly influence biotic composition, growth habits, diversity and ecosystem functions, contributing to changes in species composition. Similarly, the Himalayas exhibit a wide range of topographical heterogeneity with ecological, economic, social and cultural significances (Geneletti and Dawa, 2009; Charlery et al., 2016; Hoy et al., 2016). It also harbors one of the 36 biodiversity hotspots viz., the Himalaya, with a broad scope of endemic flora and fauna. However, Himalayan ecosystems are listed among the most threatened habitats (Schickhoff, 1995), with $23 \%$ forest cover loss from the last thirty years in Western Himalayas (Anonymous, 2005). Gradient investigations in the mountains, thus pave the way to formulate many primary ecological and evolutionary principles (McCain and Grytnes 2010; Körner 2018). 
There is logical agreement on the significance of climatic factors, geology, location, and interactions among organisms besides natural and anthropogenic interferences for forest diversity (Johnson and Miyanishi 2007). Previous studies in the Kashmir Himalayan region have investigated species richness and composition along altitudinal gradient across diverse habitats and taxa (Khuroo et al., 2011; Shaheen et al., 2012). Recent research has suggested that stand structural characteristics increase stand performance, regardless of the obstruction of species richness (Ali and Mattsson, 2017). Shaheen et al. (2012) emphasized the significance of geographical variables for large-scale species distribution trends across the Himalayas. Nonetheless, the relationship among forest structural heterogeneity, topographical variations and species composition has been genuinely underexamined. Stand structural features such as basal area (BA), diameter at breast height, and tree density can push the ecosystem diversity, interactions among organisms, gene flow and consequently forest inhabitants and overall diversity (Jafari et al., 2013). Connecting structural attributes with diversity is of extreme significance in managing forest.

The Himalayas are the tallest and longest mountain ranges with diverse landscapes (Xu, et al., 2009). They also define the climatic regime of the Indian subcontinent, besides promoting the people's livelihood (Resurreccion et al., 2019). It is assessed that $75 \%$ of the forest cover in the Himalaya was destroyed in the last century alone. Knowledge of how the nature and structure of temperate ecosystems vary across different places is crucial to set regional conservation targets. Effective conservation and management practices involve an unequivocal investigation of plant diversity patterns and an appreciation of factors regulating such patterns. Unfortunately, temperate ecosystems, particularly Himalayan forests, were underestimated for ecological studies (Peer et al., 2007) until recently and are poorly explored than their European counterparts.

All the ecological processes and functions, particularly the forest stand structure, depend significantly on trees. Moreover, density and diversity were also determined by the number of stems within the forest (Podlaski et al., 2019). Recently, several studies have focussed on trends of tree species composition, structural patterns and diversity in Himalayan temperate ecosystems along various ecological gradients, including elevation (Sharma et al., 2017; Sharma et al., 2018), disturbance (Khera et al., 2001; Gautam et al., 2016), aspect (Baduni and Sharma, 1999; Sharma et al., 2010), etc. and also across different areas of Kashmir valley (Dar et al., 2002; Khuroo et al., 2004; Khuroo et al., 2011; Dar and Sundarapandian 2016). However, the transition zone from lowlevel blue pine (BP) to subalpine (SA) forests via mixed conifer (MC) forest and also the influence of geographical variables and stand characteristics on species distribution deserves investigation. Moreover, reports documenting species diversity in these mountain ranges cover only particular regions leaving several areas unexplored. Thus, evaluation of forest composition and structure and factors influencing them in unstudied mountain environments is instrumental in understanding species density, and territories of conservational importance.

Hence, the aim of the present study was to report the outcome of intensive study of phytosociology and diameter-class complexity of tree species in low-level blue pine (BP), mixed conifer (MC) and subalpine (SA) forest types between 1800 - 3300 m a.m.s.l in temperate Kashmir Himalaya, India. Accordingly, the objectives of the work were to characterize and compare tree species composition and structure across these forest types and to examine the relationship between the tree species and environmental variables and other community features. 


\section{Materials And Methods}

\section{Study area}

The study area spans over five districts of Kashmir valley $\left(33.51^{\circ}-34.66^{\circ} \mathrm{N}\right.$ and $\left.74.02^{\circ}-75.01^{\circ} \mathrm{E}\right) \mathrm{Jammu}$ and Kashmir Union Territory, India (Fig. 1). Data on tree species abundance were collected from hitherto unstudied areas harbouring low-level blue pine (BP), mixed conifer (MC) and subalpine (SA) (Champion and Seth, 1968) in 2019 after a preliminary field survey in 2018.

Kashmir valley exhibits a warm summer and humid continental climate (Dfa; Peel et al., 2007) with four recognisable seasons. Climatic data from the last 40 years revealed a mean annual minimum and maximum temperature of $7.75^{\circ} \mathrm{C}$ and $19.98^{\circ} \mathrm{C}$ with 800 to $1200 \mathrm{~mm}$ of annual precipitation range. Due to the recurrent disturbances posed by the Mediterranean Sea in the winter season, Kashmir valley receives frequent rain and snowfall. The period of snowfall spans from as early as October and can extend up to March. Frost is a common phenomenon during this season. Geologically the study area comprises rocks from the Pre-Cambrian era chiefly composed of slates, phyllites, quartzites, etc. (Krishnan, 1982). The soil orders in the study area are deep, overwhelmingly entisols (typis udifluvents) accompanied with inceptisols (typic eutrochrepts and fluventic eutrochrepts), alfisols and mollisols (Sidhu and Surya, 2014; Mahapatra et al., 2000) with loamy texture. The whole region, especially the low altitude area, is prone to over-exploitation of non-timber forest products, land encroachment, illegal logging, over-grazing etc.

\section{Sampling design and field data collection}

A landscape-level field census was undertaken in 143 plots of 0.25 ha $(50 \mathrm{~m} \times 50 \mathrm{~m})$ area sampled across the three forest types. To overcome the bias of within-plot differences, a random sampling approach was employed within each category of the forest. Attempts were made to replicate plots evenly between the forest types; nonetheless, this was not always possible because of the logistic constraints imposed on the field survey and the availability of sites within each forest type.

\section{Field survey}

Three forest types ranging in elevation from $1800 \mathrm{~m}$ to $3300 \mathrm{~m}$ were considered for the present study after a preliminary field survey in December 2018. Fieldwork was conducted from April to July 2019. In established 50 $\mathrm{m} \times 50 \mathrm{~m}$ sampling units, abundance and diameter at breast height (DBH) at $1.37 \mathrm{~m}$ above the ground level of each tree ( $\geq 10 \mathrm{~cm}$ DBH) were recorded (Pearson et al., 2005; UNFCC, 2015). At the central point of each sampled plot, Geographical Positioning System (GPS) coordinates, elevation (m) and slope (degree) were recorded during data collection (JUNO 3E; accuracy 2 - 5m; inclinometer). Voucher specimens of all inventoried tree species were prepared and identified with Flowers of the Himalaya (Polunin and Stainton, 1984) and crossverified at Centre for Biodiversity and Taxonomy, Department of Botany, University of Kashmir.

\section{Data analysis}

The information theory-based indices analysed includes species richness (Menhinick, 1964, Shannon-Wiener index $(\mathrm{H} \square)$ (Magurran, 2004), and Fisher's Alpha index (S) (Fisher et al. 1943) as they comprehend rare species within the community; whereas, dominance measures examined was Simpson index (D) (Simpson, 1949) of 
diversity occasionally referred to as Yule index (Southwood 1978) and is biased by the abundance rather than number of species.

One of the robust and unconstrained tool of ordination in community ecology viz., NMDS (Leps and Smilauer, 2007) was used to display the general contrasts in species structure among the three forest types using tree abundance data (Legendre and Legendre, 1998). To enumerate the dis/similarity matrix, one-way Analysis Of SIMilarity (ANOSIM) statistics (Bray-Curtis distances-Bray and Curtis, 1957; 999 permutations) was executed. To determine the minimum acceptable area ideal for vegetation survey, besides comparing species assemblages, species-area curve was plotted for each forest type. Rarefaction, an interpolation method was used to estimate the expected species richness within the given number of individuals (Gotelli and Colwell, 2011). The important value index (IVI) for each species was enumerated as the entirety of phytosociological attributes; relative density, relative dominance/relative BA and relative frequency (Curtis and Mclntosh, 1950). Family importantance value (FIV) was calculated following Mori et al. (1983).

Vegetation data were used for hierarchical agglomerative Bray-Curtis (Single-linkage) clustering analysis to combine plots of similar species and relatively comparable abundance into groups (Kassambara, 2017), thereby recognising the microclimatic variability across the humid temperate ecosystems (Shaheen et al., 2012). A twosample Kolmogorov-Smirnov test was used to test the clustered groups.

The stand-structure of three forest types and stem-size distribution patterns of dominant species were assessed using tree size class distribution using DBH classes $(\mathrm{m})$ and their BA $\left(\mathrm{m}^{2}\right)$. Statistical significance of each size class distribution was tested by Kruskal Wallis test.

To visualise and summarise the inertia (information) within data, which consists of observations defined by several interrelated statistical variables, PCA was performed (Husson et al., 2017; Kassambara and Mundt, 2017). The relationship between environmental variables and tree species abundance besides within environmental variables and species were assessed by Canonical Correspondence Analysis (CCA; Ter Braak, 1987) utilising species abundance and environmental data. Permutation results were checked for model significance.

The R version 3.6.2 (R Core Team, 2019), PAST 3.26 (Hammer et al. 2001) and SPSS 25.0 statistical software also in addition to Microsoft Excel 2016 were adopted to perform the obligatory statistical data analysis.

\section{Results}

\section{Compositional attributes}

\section{Species composition}

From the total 143 plots of 0.25 ha (35.75 ha area) of three temperate forest types of Kashmir Himalaya, India, altogether 7808 trees $(\geq 10 \mathrm{~cm} \mathrm{DBH})$ were enumerated, which belonged to 13 species, 13 genera and 8 plant families. Tree density was lowest (191.25 ha $\left.{ }^{-1}\right)$ in BP forest, moderate (228.92ha-1) in MC forest and maximal $\left(232.72 \mathrm{ha}^{-1}\right)$ in SA forest (Table 1). 
The species richness in three forest types varied from five species in SA forest and six in BP to a maximum of ten species in the MC forest. Out of 13 species, seven (53.9\%) were hardwood deciduous species, while the remaining six were evergreen coniferous species. One singleton species Robinia pseudoacacia, with just a single individual across the landscape, was confined to MC forest. Furthermore, uniques (species restricted to only one sample plot), two in BP forest (Populus nigra and Juglans regia) and three in MC forest (Juglans regia, Aesculus indica and Robinia pseudoacacia) were present. One duplicate (species present in only two sample plots) occurred in MC forest. However, no uniques or duplicates occurred in SA forest. Besides species richness in BP and SA forests, diversity indices varied across forest types. MC forest being most diverse, has eminent $\mathrm{H} \square$ (1.1), D (0.6) and S (2.1) indices among the three forest types. The D scores unveiled just $37 \%$ randomly chosen pairs consist of different species indicating overall low diversity across the landscape. Regression analysis displayed an influence of elevation on species count within forest types $\left(R_{\mathrm{BP}}^{2}=0.04, R_{\mathrm{MC}}^{2}=0.02, R_{\mathrm{SA}}^{2}=0.05\right)$ and also across the landscape $\left(R^{2}=0.07\right)$. Moreover, the number of species displayed a significant positive correlation with elevation $\left(r_{s}=0.237, p \otimes 0.01\right)$ and density $(r s=0.18, p \otimes 0.05)$. Abundance scores revealed that BP and SA forests are monospecific dominant forest dominated by Pinus wallichiana (60.23\%) and Abies pindrow (76.44\%), respectively, whereas, MC forest dominance was shared by Abies pindrow (46.12\%; dominant) and Pinus wallichiana (38.77\%; codominant). Three species Abies pindrow, Pinus wallichiana and Picea smithiana were widespread and occurred in all three forest types (Table 1).

Table 1 Summary of tree inventory in low-level blue pine (BP), mixed conifer (MC) and subalpine (SA) forests of temperate Kashmir Himalaya, India 


\begin{tabular}{|c|c|c|c|c|}
\hline Variable & BP forest & $M C$ forest & SA forest & Landscape-level \\
\hline $\begin{array}{l}\text { Tree abundance on } \\
\text { plots (area sampled in } \\
\text { ha) }\end{array}$ & $1529(8)$ & $4460(19.5)$ & $\begin{array}{l}1919 \\
(8.25)\end{array}$ & 7908 (35.75) \\
\hline $\begin{array}{l}\text { Tree density (stems ha' } \\
{ }^{-} \text {) }\end{array}$ & 191.25 & 228.92 & 232.72 & 221.20 \\
\hline Mean DBH (cm) & 46.96 & 52.62 & 55.06 & 52.12 \\
\hline Max. DBH (cm) & 207.01 & 226.11 & 254.78 & 254.78 \\
\hline Total basal area $\left(\mathrm{m}^{2}\right)$ & 367.90 & 1244.23 & 614.79 & 2226.92 \\
\hline Basal area $\left(\mathrm{m}^{2} \mathrm{ha}^{-1}\right)$ & 45.88 & 63.81 & 74.52 & 62.29 \\
\hline Total no. of species & 6 & 10 & 5 & 13 \\
\hline $\begin{array}{l}\text { Dominant species \& \% } \\
\text { abundance }\end{array}$ & $\begin{array}{l}\text { Pinus } \\
\text { wallichiana } \\
, 60.23 \%\end{array}$ & $\begin{array}{l}\text { Abies pindrow, } 46.12 \% \text { \& } \\
\text { Pinus wallichiana; } \\
38.77 \%\end{array}$ & $\begin{array}{l}\text { Abies } \\
\text { pindrow, } \\
76.45 \%\end{array}$ & $\begin{array}{l}\text { Abies pindrow, } 46.51 \% \text { \& } \\
\text { Pinus } \\
\text { wallichiana; } 37.41 \%\end{array}$ \\
\hline \multicolumn{5}{|l|}{ Diversity indices } \\
\hline $\begin{array}{l}\text { Species richness } \\
\left(d=S / N^{1 / 2}\right)\end{array}$ & 0.15 & 0.15 & 0.11 & 0.15 \\
\hline $\begin{array}{l}\text { Shannon-Weaver Index } \\
(\mathrm{H} \square)\end{array}$ & 0.8 & 1.13 & 0.63 & 1.2 \\
\hline $\begin{array}{l}\text { Simpson diversity } \\
\text { Index (D) }\end{array}$ & 0.47 & 0.62 & 0.37 & 0.63 \\
\hline Fisher's a index (S) & 0.96 & 2.14 & 0.68 & 3.02 \\
\hline $\begin{array}{l}\text { No. of evergreen } \\
\text { species, their } \\
\text { abundance and \% }\end{array}$ & $\begin{array}{l}4,1521 \\
99.48\end{array}$ & $5,4423,99.17$ & $\begin{array}{l}3,1879 \\
97.86\end{array}$ & $6,7822,98.91$ \\
\hline $\begin{array}{l}\text { No. of deciduous } \\
\text { species, their } \\
\text { abundance and \% }\end{array}$ & $2,8,0.52 \%$ & $5,37,0.83 \%$ & $\begin{array}{l}2,41 \\
2.13 \%\end{array}$ & $7,86,1.08$ \\
\hline
\end{tabular}

There were no predictable contrasts in tree community composition due to a strong overlap among the studied forest types (Stress $=0.08 ; R^{2}=0.99$ ). Out of 13 tree species documented, just three species were shared among the three forest types (Fig. 2).

One-way non-parametric ANOSIM revealed an overall compositional dissimilarity among forest types $(R=0.12$; $p=0.001)$. Pairwise examination of forest types indicated that structural composition of BP forest varied considerably from MC $(p \otimes 0.001)$ and $S A(p \otimes 0.001)$ forests, although there were no noteworthy distinctions between MC and SA forest $(p=0.8)$ combinations. (Fig. S1).

\section{Species accumulation and rarefaction curves}


Species accumulation curve of BP, MC and SA forests for sampled plots 32, 78 and 33 respectively exhibited a monotonic increase and reached more or less an asymptote indicating that sufficient area was sampled (Fig. S2). In contrast to BP and MC forests, species-area curve of SA forest levelled off quickly after 4.25 ha (17 plots) of sampling. The number of species ranged from five to ten across the three forest types with six, ten and five species in BP, MC and SA forests, respectively. In BP and MC forests, $50 \%$ of species were trapped within $12.5 \%$ ( $1 \mathrm{ha}$ ) and $12.8 \%$ (2.5 ha) sampled area, whereas it looks only slightly greater than $6.06 \%$ (0.5 ha) area to capture $60 \%$ of species count in SA forest. Plot-based rarefaction curves of BP, MC and SA forests attained an asymptote and the number of individuals to attain maximal within plot diversity ranged from just one to $\nabla 50$ individuals. Bi-plot species richness in MC forest was maximum for plot MC-54 with five species, while in SA and BP forests with a maximum of four and three species in $4^{\text {th }} / 8^{\text {th }} / 17^{\text {th }}$ and $7^{\text {th }} / 28^{\text {th }}$ plots, respectively (Fig. 3).

\section{Important value index (IVI), and family composition}

Across the landscape, three abundant and frequent species; Abies pindrow (46.4\%), Pinus wallichiana (36.2 \%) and Picea smithiana (11.0 \%) shared $>90$ \% of IVI. Pinus wallichiana (206.1) among the species inventoried in BP forest exhibited maximum IVI followed by Cedrus deodara (45.2) and Abies pindrow (25.7). However, in MC and SA forests Abies pindrow $(135.7 ; 216.7)$ followed by Pinus wallichiana $(108.4 ; 46.8)$ were the most important species.

The tree species enumerated across landscape belonged to a total of eight families with three evergreen and five deciduous species. Taxonomically, Pinaceae was the most diverse and abundant family with four (30\%) species accounting for more than $98 \%$ of total tree abundance, followed by Betulaceae and Sapindaceae with two species each. A significant variation in family richness was observed among the three forest types $(F=7.77$, $p=0.0004$ ). Among the forest types, MC was most diverse and speciose forest comprising of 10 species of seven families and 4460 tree individuals as compared to BP and SA forests with six and five species, respectively. At landscape level, five families harboured single species. Apart from being the only family common to all the three forest types, the Pinaceae was dominant $\left(F_{\mathrm{BP}}=293.59 ; \mathrm{FIV}_{\mathrm{MC}}=278.75\right.$ and $\mathrm{FIV}$ SA 284.57), followed by Salicaceae (FIV = 3.33), Sapindaceae (FIV = 6.90) and Betulaceae $(F I V=14.40)$ in BP, MC and SA forest respectively (Table S1).

\section{Cluster analysis}

In BP forest, the optimal number of clusters with maximal average Silhouette width represented two major clusters excluding an outlier (BP-1), which appeared as a distinct cluster (Fig 4a). Two-sample KolmogorovSmirnov test for the distribution of individuals among the clusters proved to be insignificant $(D=0.67, p=0.14)$.

In MC forest, irrespective of a couple of outliers (MC-41 and MC-47), two principal clusters with an agglomerative coefficient of 0.8 seemed to be more informative as per the average Silhouette method (Fig. $4 \mathrm{~b}$ ). Nevertheless, in relation to BP forest, statistical analysis unveiled an insignificant distribution of individuals between the clusters $(D=0.3, p=0.75)$ in MC forest. SA forest, in contrast to BP and SA forests, formed a single large cluster with a relatively low agglomerative coefficient of 0.7 (Fig 4c).

\section{Structural heterogeneity}

\section{Stand density and basal area (BA)}


The cumulative tree density and BA of the study plots from the three temperate forests were 7908 individuals and $2226.9 \mathrm{~m}^{2}$ in 35.6 ha area (Table 2). Tree density and BA ranged from a low of 72 stems ha $^{-1}$ in SA forest to as high as 924 stems ha-1 in BP forest and $13.0 \mathrm{~m}^{2} \mathrm{ha}^{-1}$ and $125.7 \mathrm{~m}^{2} \mathrm{ha}^{-1} \mathrm{BA}$ in MC forest respectively.

Tree density did not vary significantly among the three forest types $(F=1.159, p=0.317)$. In BP forest, mean stand density $\left(191.1 \pm 29.2\right.$ stems ha $\left.^{-1}\right)$ was lower than overall mean stand density $\left(221.2 \pm 10.6\right.$ stems ha $\left.^{-1}\right)$ in contrast to MC forest $\left(228.7 \pm 12.8\right.$ stems ha $\left.^{-1}\right)$ and SA forest $\left(232.6 \pm 20.6\right.$ stems ha $\left.^{-1}\right)$. Furthermore, stand density in sampled plots of MC and SA forests, ranged from $72-632$ stems ha $^{-1}$ and $72-628$ stems ha $^{-1}$ respectively whereas, it was markedly greater $72-924$ stems $^{-1} \mathrm{ha}^{-1}$ in BP forest.

A considerably significant variation in BA was obtained across the three forest types $(F=9.824, p \otimes 0.001)$ principally contributed by BP-SA and MC-BP forest pairs (Fig. S3a). Tree BA was maximum $74.5 \pm 4.5 \mathrm{~m}^{2} \mathrm{ha}^{-1}$ in SA forest followed by $63.8 \pm 2.9 \mathrm{~m}^{2} \mathrm{ha}^{-1}$ and $46.0 \pm 3.6 \mathrm{~m}^{2} \mathrm{ha}^{-1}$ in MC and BP forests respectively. Further, mean $\mathrm{BA}$ in MC and SA forest stands was more remarkable than landscape-level mean stand BA $\left(62.3 \pm 2.2 \mathrm{~m}^{2} \mathrm{ha}^{-1}\right)$. Although BA displayed different elevation patterns within three forest types, BA across the landscape showed a hump-shaped pattern, which decreased rapidly towards the end with elevation.

\section{Density and diversity-diameter class distribution pattern}

Tree density, species count and $\mathrm{H} \mathbb{\nabla}$ followed an inverse trend with larger diameter classes from $10-270 \mathrm{~cm}$ leading to nearly a hierarchical pattern. Nonetheless, species occurrence rate defined as the ratio of species count to density increased proportionally with increasing diameter class. Notably, the contribution of the lowest diameter class was $26.3 \%$ to all individuals inventoried and $92.3 \%$ to all total species count encountered (Table S2). Moreover, an insignificant dissimilarity is evident in the share of trees segregated into 12 diameter classes to density $(F=0.07294, p=0.9298)$ and number of species $(F=1.018, p=0.3725)$.

The density-diameter distribution followed the above-generalised pattern, besides $30-50 \mathrm{~cm}$ and $10-30 \mathrm{~cm}$ classes in BP and MC forests, respectively, in which density of former class was less than the subsequent diameter class. Relative distribution of density to various diameter classes revealed that threshold diameter class $(10-30 \mathrm{~cm})$ in BP forest shared $38 \%$ of all individuals whereas, it was only $24.57 \%$ and $22.76 \%$ in SA and MC forests. Notably, in MC forest, $60-90 \mathrm{~cm}$ class scored $3.36 \%$ greater density than lowest diameter class.

Species diameter-dominance does not show much variation in three forests. Although species diameterdominance does not vary in SA forest $(10-190 \mathrm{~cm})$, BP and MC forests displayed a shift from Pinus wallichiana $(10-110 \mathrm{~cm})$ to Abies pindrow $(110-150 \mathrm{~cm})$ and again to Pinus wallichiana $(190-210 \mathrm{~cm})$, and Abies pindrow $(10-170 \mathrm{~cm})$ to Picea smithiana $(170-230 \mathrm{~cm})$, respectively (Table S2).

The relative distribution of species and $\mathrm{H} \otimes$ to lower diameter class among three forests ranged from a low of four (in BP forest) and 0.64 (in SA forest) to 10 (in MC forest) and 1.20 (in BP forest). In contrast to MC and SA forests, species count was maximum in diameter class subsequent to threshold diameter class in BP forest. Similarly, besides MC forest, $\mathrm{H} \mathbb{Z}$ scores in BP and SA forests were maximum in diameter classes $(90-110 \mathrm{~cm}$ \& $50-70 \mathrm{~cm}$ ) rather than threshold diameter class. Maximum species count reduction with diameter class was displayed in MC forest (ten-fold), followed by SA forest (five-fold) and least in BP forest (four-fold). Species 
occurrence rate scores among three forests were maximum in MC forest in $170-190 \mathrm{~cm}$ class followed by SA forest in $250-270 \mathrm{~cm}$ and BP forest in $190-210 \mathrm{~cm}$ class. 3.2.1. The forest stand-structural heterogeneity

Abundance-based stand structure of BP, MC and SA forests exhibited a reverse J-shaped pattern with abundance frequency distribution declining with respect to increasing diameter class (Fig. 5). The difference in the distribution of individuals to various size classes was significant (Kruskal-Wallis $\chi^{2}=32.06 ; \mathrm{df}=11 ; p=$ 0.0007) among the three forest types (Fig. S3b). More than $50 \%$ of individuals fell within the first three diameter classes. The lowest diameter class $(10-30 \mathrm{~cm}$ ) share to abundance in MC forest accounted for $22.8 \%$, lower than two successive diameter classes, i.e., $30-50 \mathrm{~cm}(26.1 \%)$ and $50-70 \mathrm{~cm}(26.1 \%)$; nonetheless, the trend is quite reverse in BP and MC forests. Although the diameter class distribution pattern in SA and BP forests were more or less similar, there was a sharp decline in MC forest due to very dense first three diameter classes than other two forests. Among the forest types, mean DBH was maximum in SA forest $(55.1 \mathrm{~cm})$ followed by $\mathrm{MC}$ forest $(52.6 \mathrm{~cm})$ and least in BP forest $(47.0 \mathrm{~cm})$, thus indicating greater frequency of large-diameter class trees as compared to small-sized trees in SA forest. Moreover, trees with maximum DBH across sampled plots were found in SA forest. Except for one or more diameter class gaps in

all three forest types, none of them harboured even a single tree in $230-250 \mathrm{~cm}$ class, although $250-270 \mathrm{~cm}$ size class featured in SA forest.

Nevertheless, with regard to BA, stand structure unveiled an asymmetric Gaussian or bell-shaped curve with a smaller BA in highly dense lower diameter class, reaching a maximal between $70-110 \mathrm{~cm}$ class across the forest types, and lowered towards the end. Distribution of BA to various diameter classes among the three forest types varied significantly (Kruskal-Wallis $\chi^{2}=31.26$; $\mathrm{df}=11 ; p=0.001$, Fig. S3c). The $R^{2}$ values for abundance and BA varied between 0.64 to 0.80 and 0.37 to 0.39 , respectively, for BP and SA forests and were found statistically significant in all three forest types (Fig. 5).

\section{Stem size heterogeneity of dominant species}

Structural heterogeneity of top three dominant species drawn by analysing diameter class frequency distribution and BA varied within species in three forest types (Fig. S4). By forest type, dominant species with maximum abundance also varied: Pinus wallichiana in BP forest and Abies pindrow in both MC and SA forests. Generally, the abundance of each dominant species in three forest types declined with size class increase. However, structural pattern ranged from perfect 'L' or reverse J-shaped distribution in Abies pindrow and Picea smithiana within MC and SA forests to asymmetric inverse J-shaped curve holding at a minimum one missing or less dense size class other than lower size class as in Cedrus deodara. Moreover, an inverse J-shaped pattern with lesser number of individuals in threshold diameter-class than subsequent classes, as depicted in Pinus wallichiana and Abies pindrow in BP forest and asymmetric normal or bell-shape resulted from the preponderance of individuals in middle size class as displayed in Pinus wallichiana within SA forest. The regression coefficient $\left(R^{2}\right)$ with level of significance $(p)$ value for abundance varied from species to species. The $R^{2}$ with $p$-value ranged from 0.505 to 0.933 with $p \otimes 0.001$ to $\otimes 0.05$. Notably, the highest $R^{2}$ with $p$-values was 0.933 with $p \otimes 0.001$ for Picea smithiana in MC forest indicating a highly significant correlation between the size class and abundance. 
The BA distribution followed a trend of asymmetric Gaussian or normal curves for all dominant species except Picea smithiana from MC forest (Fig. S4b). Tree species with the maximal BA were the same with maximum abundance, thus alluded to a considerable number of individuals in higher diameter classes. The BA $R^{2}$ with $p$ value ranged from 0.123 for Cedrus deodara in BP forest with $p \otimes 0.001$ and Pinus wallichiana in SA forest with $p \otimes 0.05$, to 0.244 with $p=0.08$ for Abies pindrow in BP forest.

\section{Distribution patterns}

Variables on the PCA plot diagram are scattered based on their correlations. A longer distance between origin and projected variable as in mean $\mathrm{BA}, \mathrm{H} \mathbb{\text { }}$, and smaller angles among the variables respectively indicated a greater quality of the variable and relevance among one another (Fig. 6). The mean DBH, mean BA, H区 and also species count, and S (although less than the former three) exhibited high $\cos ^{2}$ values, thus well represented and were positioned adjacent to the perimeter. However, more than two components were required to thoroughly interpret the variables closer to the point of commencement.

Eigenvalues, an estimate of the magnitude of total inertia retained by each dimension, were examined to determine the estimated number of dimensions. As eigenvalues consistently decrease with the number of dimensions, the top five principal components with eigenvalues above one accounted for more than $80 \%$ of total inertia, hereafter the residual scores were comparatively insignificant and were analogous to one another

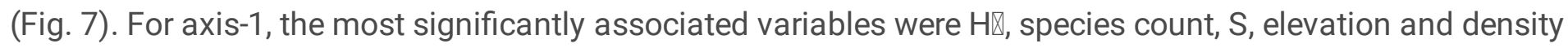
with $p \otimes 0.0001$, thus interpreted as diversity axis, as diversity indices explained $>80 \%$ of inertia of the given axis. The below expected average contribution variables followed the order: UTM-E (Universal Transverse Mercator easting) $\nabla$ slope $\nabla$ UTM-N (Universal Transverse Mercator northing) $\nabla$ aspect $\nabla$ mean BA $\nabla$ density $\nabla$ mean DBHQ $\triangle$ elevation. Nonetheless, variables such as mean BA, mean DBH, density, etc., were significantly associated with axis 2 ( $p \otimes 0.0001)$. However, lower scores of the order of magnitude were UTME-E $\otimes$ slope $\otimes$ UTM-N $\nabla$ aspect $\nabla$ mean BA $\otimes$ density $\nabla$ elevation $\otimes$ mean DBH. Although significant variables contribute $>85 \%$ of total inertia to axis 2 , altogether $23.6 \%$ of total inertia or variance was interpreted by dimension-2. Subsequent dimensions lacked considerable interpretation power.

Individual plots and variables positioned on the same side indicated a high value of the latter for the former and vice versa. In Fig. 7, most of the BP forest plots were concentrated opposite to diversity indices (species count, $H \mathbb{Z}$, and $S$ indices) and elevation and in positive direction with well-represented dominance and poorly interpreted aspect and UTM-E; in contrast, most of the plots of MC forest were scattered almost all over the factor map. Further, projection points of some SA and MC forests plots scattered in the direction of mean DBH, mean BA, and also towards density, UTM-N and slope projection, thus indicated an association between stand characteristics and location features.

Among all documented variables, elevation and slope formed the principal environmental factors restricting the tree abundance and species distribution as indicated by the length of projections in the CCA plot (Fig. 7).

Eigenvalues for the first two axes were 0.21 (CCA1) and 0.09 (CCA2) with a total of $93.59 \%$ of explained inertia of tree species variability ( $p=0.001$; Table 2$)$. The first axis (CCA1) explained $63.81 \%$ of data inertia and was mainly related to elevation, thus separating low elevation tree species (Cedrus deodara, Robinia pseudoacacia, 
Aesculus indica, etc.) from higher ones $(p=0.001)$, mainly Betula utilis (Table 2). Similarly, the second axis (CCA2) was related to the rest of the variables, particularly slope $(p=0.008)$ and interpreted $29.78 \%$ of the explained variance. However, the second axis mainly bifurcated tree species of steep (Taxus baccata and Acer caesium) and gentle slopes (Juniperus macropoda, Cedrus deodara, etc.; Fig. 7).

Table 2 Summary of CCA analysis. (VIF; variance inflation factor, UTM-E; universal transverse Mercator-easting, UTM-N; universal transverse Mercator-northing)

\begin{tabular}{|c|c|c|c|c|c|c|c|c|c|c|}
\hline \multicolumn{6}{|l|}{ VIF } & \multicolumn{5}{|c|}{ Eigenvalue (\% explained inertia) } \\
\hline $\begin{array}{l}\text { UTM- } \\
\text { E }\end{array}$ & $\begin{array}{l}\text { UTM- } \\
\text { N }\end{array}$ & Elevation & Slope & \multicolumn{2}{|l|}{ Aspect } & CCA1 & CCA2 & ССАЗ & CCA4 & CCA5 \\
\hline 1.15 & 1.53 & 1.04 & 1.47 & \multicolumn{2}{|l|}{1.01} & $\begin{array}{l}0.21 \\
(63.81)\end{array}$ & $\begin{array}{l}0.098 \\
(29.78)\end{array}$ & $\begin{array}{l}0.013 \\
(3.95)\end{array}$ & $\begin{array}{l}0.006 \\
(1.82)\end{array}$ & $\begin{array}{l}0.002 \\
(0.60)\end{array}$ \\
\hline \multicolumn{6}{|c|}{$\begin{array}{l}\text { Permutation test for testing significance of CCA } \\
\text { model }\end{array}$} & \multicolumn{5}{|c|}{$\begin{array}{l}\text { Permutation test the significance of first CCA } \\
\text { axis }\end{array}$} \\
\hline & $x^{2}$ & F-value & \multicolumn{3}{|l|}{$p$-value } & & $x^{2}$ & $\begin{array}{l}\text { F- } \\
\text { value }\end{array}$ & \multicolumn{2}{|l|}{$\begin{array}{l}p- \\
\text { value }\end{array}$} \\
\hline & 0.331 & 2.31 & \multicolumn{3}{|l|}{0.001} & & 0.21 & 7.327 & \multicolumn{2}{|l|}{0.001} \\
\hline \multicolumn{11}{|c|}{ Permutation test for testing significance of environmental variables } \\
\hline & & & & $x^{2}$ & $\begin{array}{l}\text { F- } \\
\text { value }\end{array}$ & \multicolumn{5}{|l|}{$p$-value } \\
\hline & & & Elevation & 0.174 & 6.13 & \multicolumn{5}{|l|}{0.001} \\
\hline & & & Slope & 0.079 & 2.8 & \multicolumn{5}{|l|}{0.01} \\
\hline
\end{tabular}

\section{Discussion}

The number of tree species in the three forest types of Kashmir Himalaya ranged from five to ten, and this is congruent with various phytosociological studies from Himalayan forest ecosystems (Khera et al., 2001; Khera et al., 2001; Khera et al., 2001; Pandey et al., 2018), and also from the Alps in vicinity of Austrian border (Karrenberg et al., 2003) and Ontake forest reserve, Honshu Island, Japan (Miyadokoro et al., 2003). The number of tree species is, however, lower than those of the western part of Central Himalaya, Uttarakhand (India) with 16 tree species (Semwal et al., 2010), South Island of Tsushima (Japan) with 45 woody species (Manabe et al., 2000), and Dolpa district in rain shadow of north-western Nepal with 16 tree species (Kunwar et al., 2004). Although a decrease in the number of species with elevation is considered as a general pattern (Francis and Currie, 1998), consistent with the present study, the number of species was greater in the mid-elevation zone similar to the results reported by Lomolino (2001), Alexander et al. (2011) and Fosaa (2004) that was occupied by $\mathrm{MC}$ forest in our study area. This can be explained by Gleason's individualistic concept of plant assemblages, which stipulates that the dissemination of every species is driven by its own ability to endure, contend and 
reproduce effectively in prevailing environmental conditions (Gleason, 1926). In the Himalayan region, a slight variation in the number of species within the elevation range of $1500 \mathrm{~m}-2500 \mathrm{~m}$ subsequently decreases with rising elevation (Grytnes and Vetaas, 2002). Nonetheless, microclimate with variability in edaphic properties and differences in aspect and direction of the studied sites could have possibly resulted in such trends (FerrerCastán and Vetaas, 2003).

The $H \otimes$ of diversity scores for the present study is within the published estimate of 0.28 to 1.75 (Sharma et al., 2010) and 0.4 to 2.8 (Singh et al., 1994) for the Himalayan range. However, D values were lower than the Western Himalayan forests of Kashmir, Pakistan, as reported by Shaheen et al. (2012). A negative association between evenness and elevation was found in the studied forests, decreasing linearly with elevation, in contrast to studies from other parts of Himalaya (Dar and Sundarapandian, 2016; Shaheen et al., 2012). Furthermore, low evenness scores in SA forests among the three forest types may be due to competing out the other species for resources by dominant ones (Murcia 1995).

The recorded stand density in the studied three forest types was within the range reported for other Himalayan

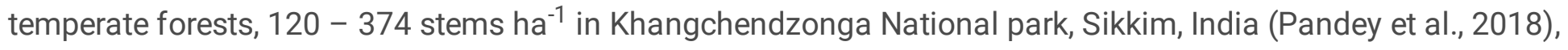
90 - 277 stems ha $^{-1}$ in Western Himalaya, Pakistan (Shaheen et al., 2012), 170 - 283 stems ha $^{-1}$ in Central Himalaya, India (Chaturvedi and Singh, 1986), 103 - 1201 stems ha $^{-1}$ in North-western Himalaya, India (Dar and Sundarapandian 2016) and elsewhere, 216 - 874 stems ha $^{-1}$ in Northern New Zealand (Ahmed and Ogden, 1987) and 24 - 930 stems ha $^{-1}$ in Suleiman Range, Zhob city, Pakistan (Ahmed et al., 1991). However, it was lower when compared to the reported density of $540-708$ stems ha-1 $^{-1}$ in ridge forests, Garhwal Himalaya, India

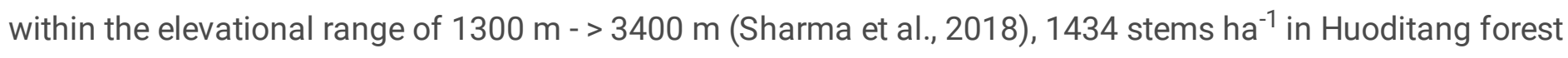
region, North-western China (Kang et al., 2017), 295 - 850 stems ha $^{-1}$ in Central Himalaya (Sharma et al., 2010) and 754 stems ha-1 $^{-1}$ in Ontake forest reserve, Honshu Island, Japan (Miyadokoro, et al., 2003). The lower density in the BP forest among the three forest types might be due to various anthropogenic disturbances such as the illegal felling of Pinus wallichiana and Cedrus deodara. Furthermore, uncontrolled grazing and extraction of non-timber forest products (NTFPs) in these forest stands could have affected the regeneration process. Overall, Kashmir Himalaya recorded a low tree density than the rest of the Himalayan regions, probably attributable to prolonged cold winter spanning about five months.

The BA has been considered as one of the robust components to study the vegetation structure within forest stands (Pragasan and Parthasarathy, 2010). In our study, the BA ranged from $45.88-74.52 \mathrm{~m}^{2} \mathrm{ha}^{-1}$, indicating an overall good forest stand structure. The BA reported by Kunwar et al. (2004) (90.1 - $\left.151.9 \mathrm{~m}^{2} \mathrm{ha}^{-1}\right)$ in Nepal, Pande (2001) (86 - $\left.129 \mathrm{~m}^{2} \mathrm{ha}^{-1}\right)$ in Garhwal, India exceeds our documented range. However, Shaheen et al. (2012) reported closer BA values from the Western Himalayan temperate forests of Kashmir, Pakistan. Due to the extremely limited stocking of large-sized trees, BP forest displayed a low BA among the three forest types. The absence of such large size class trees points to anthropogenic disturbances as the fundamental cause mostly during the 1990s. The unconditional felling of middle and large size class of Pinus wallichiana and Cedrus deodara trees during the 1990s forestalled recovery and resilience, and in our inventory, trees that have attained larger size class were those older trees which existed before 1990s.

Cluster analysis results based on tree abundance and inventoried tree species in three different forest types indicated two different associations in BP and MC forest besides outliers in contrast to SA forest where there 
were no such associations (Fig. 4).

Distribution of tree individuals across various diameter classes implies onsite resource utilisation by the tree crop (Pragasan and Parthasarathy, 2010) and also affects multifunctionality and species diversity through multiple ecological processes within forest ecosystems (Yuan et al., 2018). A smaller tree number in the lower and medium-size classes indicates a lesser utilisation of land resources by the trees (Hitimana et al., 2004). An inverse ' $J$ ' or perfect 'L' shaped pattern of diameter class distribution is characteristic for forests with a good regeneration process (Khamyong et al., 2004) and also for undisturbed forests. The patterns were in agreement with the Western part of the Himalayas (Dar and Sundarapandian, 2016). Nevertheless, when examined by forest type and dominant species within forest types, the differences in the pole sizes, particularly in $30-50 \mathrm{~cm}$ and $10-30 \mathrm{~cm}$ dbh classes, were apparent in the BP and MC forests respectively, correspondingly as in Pinus wallichiana among all three forest types (Fig. S4). This disparity is less apparent in SA forest. Multimodal distributions of the size classes are generally demonstrative of disturbance influence in the area (Spies, 1998). Typically, old-growth forests entering an equilibrium state show a lopsided size structure (Leak, 1996); however anthropogenic interventions, for example, selective logging, expels trees and opens the canopy permitting new regeneration and establish uni-, bi-, and multimodal distributions.

The most abundant species are regularly used to characterise the forest structure (Valencia et al., 2004) and in the present study, the most abundant species include Abies pindrow, Pinus wallichiana, Picea smithiana, and Cedrus deodara contributed more than 98 \% (7761 stems in 35.75 ha) of total tree abundance. Similarly, Abies pindrow and Pinus wallichiana were recorded as abundant tree species in Indian temperate Himalaya and elsewhere (Kunwar et al., 2004; Gairola et al., 2010; Shaheen et al., 2012). The occurrence of common dominant species across all three forest types may be attributed to wind dispersal syndrome, characteristic in these habitats. This dispersal mechanism represents a significant method for translocation of species to isolated environments of similar climatic patterns (Jacobi and Carmo, 2011).

Pinaceae (represented by four species), Betulaceae and Sapindaceae (two species each) in the inventoried 35.75 ha area of the present study constituted the most speciose families, while Gairola et al. (2010) also found Pinaceae with five tree species as the dominant one in 0.2 ha in community forests of Dolpa district, Nepal.

The association among the tree species concludes their almost equivalent response to prevailing environmental conditions (Fig. 2). The CCA plot demonstrated that environmental variables viz., elevation and slope were the major operational factors in influencing the species distribution within the studied area (Fig. 7). In CCA analysis, CCA1 is considered to be the most influencing axis (Gebrehiwot et al., 2018), thus indicating that elevation governs the distribution of species in the present study as also reported by Gebrehiwot et al. (2018) from Abune Yosef mountain, Ethiopia; Sharma et al. (2018) from Bhagirathi catchment area of Garhwal Himalaya, India; Irl et al. (2015) from La Palma of Canary Islands, Spain; Shaheen et al. (2012) from Western Himalaya, Pakistan, were also reported the influence of elevation on species distribution pattern. As the elevation difference between the minimum and maximum elevation is $1500 \mathrm{~m}$, this trend certainly represents environmental variations between locations such as climate and soil changes.

In contrast to elevation, topographical factors such as slope and aspect were strongly correlated to CCA2 and also play a significant role in growth, diversity, and dispersal of tree species in the present context. This could be because topographical factors are known to influence both edaphic (physical and chemical properties of the

Page 14/27 
soil) notably soil moisture (Parker 1991), water retention (Sariyildiz et al., 2005) and transport and retention of nutrients (Zuo et al., 2012) and biotic parameters of the area, such as forest productivity (Hutchins et al. 1976), thus indirectly affecting the distribution of tree species (Dessalegn et al., 2014; Wang et al., 2016; Gebrehiwot et al., 2018).

\section{Conclusions}

The quantitative landscape-level inventory of diversity in low-level blue alpine (BA), mixed conifer (MC) and subalpine (SA) forests of temperate Kashmir Himalayas, India revealed an overall low diversity with more or less heterogeneous tree composition. The species diversity across the three forest types was maximum in MC forest (mid-elevation zone) followed by BP and SA forests. Three coniferous tree species Abies pindrow, Pinus wallichiana and Picea smithiana were shared by all three forest types. The ordinations revealed elevation and slope as principal drivers that affect species distribution across the forest types. The research data generated on forest tree diversity and stand structure from this study will be valuable and can potentially be utilised for conservation and management of forest of the three studied temperate coniferous forests and similar temperate forests.

\section{Abbreviations}

ANOSIM: Analysis of similarity; BA: Basal area; BP: Low- level blue pine; CCA: Canonical correspondence analysis; D: Simpson diversity Index; DBH: Diameter at breast height; FIV: Family importance value; GBH: Girth at breast height; GPS: Geographical Positioning System; H囚: Shannon-Weaver Index; IVI: Important value index; MC: Mixed conifer; NMDS: Non-metric multidimensional scaling; NTFPs: Non-timber forest product; PCA: Principal component analysis; S: Fisher's a index; SA: Sub-alpine; SPSS: Statistical Package for the Social Sciences; UTM-E: Universal tranverse mercator easting; UTM-N: Universal tranverse mercator northing; VIF: Variance inflation factor.

\section{Declarations}

\section{Acknowledgements}

Authors thank Jammu and Kashmir Forestry Department, for permission to carry out the field research work. Thanks to Naveen Babu for his suggestions, and Ayushi Kurian, Institut Français de Pondichéry, and Devika Menon, Kerala Forest Research Institute (KFRI), for GIS-related assistance. Three field assistants Bilal Ahmad, Basharat Ahmad and Mushtaq Ahmad rendered valuable help in the field.

\section{Authors' contributions}

AAD and NP added to the study plan; AAD collected the data, did the analysis and wrote the manuscript under the supervision of NP.

\section{Funding}

Author AAD expresses gratitude to University Grant Commission (UGC), Ministry of Human Resource Development, for monetary support through Junior Research Fellowship (UGC-JRF) UGC-Ref. No.: 3796/(NET- 
JULY 2018).

\section{Availability of data and materials}

The datasets used and/or analyzed during the current study are available from the corresponding author on reasonable request.

\section{Ethics approval and consent to participate}

Not applicable.

\section{Consent for publication}

Not applicable.

\section{Competing interests}

The authors declare that they have no competing interests.

\section{References}

1. Ahmed M, Ashfaq M, Amjad M, Saeed M (1991) Vegetation structure and dynamics of Pinus gerardiana forest in Balochistan, Pakistan. J Veg Sci 2:119-124

2. Ahmed M, Ogden J (1987) Population dynamics of the emergent conifer (Agathis australis (D Don) Lindl (kauri) in New Zealand I Population structures and tree growth rates in mature stands. N Z J Bot 2:217-229

3. Alexander JM, Kueffer C, Daehler CC, Edwards PJ, Pauchard AB, Seipel T, MIREN Consortium (2011) Assembly of non-native floras along elevational gradients explained by directional ecological filtering. Proc Natl Acad Sci USA 108:656-661

4. Ali A, Mattsson E (2016) Individual tree size inequality enhances aboveground biomass in homegarden agroforestry systems in the dry zone of Sri Lanka. Sci Total Environ 575:6-11

5. Anonymous (2005) FSI (Forest Survey of India): The state of forest report 2005 Deh-radun: FSI, Ministry of Environment and Forests Government of India

6. Badgley C, Smiley TM, Terry R, Davis EB, DeSantis LR G, Fox DL, Hopkins SSB, Jezkova T, Matocq MD, Matzke N, McGuire JL, Mulch A, Riddle BR, Roth VL, Samuels JX, Strömberg CAE, Yanites BJ (2017) Biodiversity and topographic complexity: modern and geohistorical perspectives. Trends Ecol Evol 32:1-16

7. Baduni NP, Sharma CM (1999) Community structure and growing stock variation in Quercus floribunda forest on different aspects of Garhwal Himalaya Bangladesh. J Forest Sci 28:82-93

8. Barthlott W, Mutke J, Rafiqpoor MD, Kier G, Kreft H (2005) Global centres of vascular plant diversity. Nova Acta Leopold 92:61-83

9. Bray JR, Curtis JT (1957) An ordination of the upland forest communities in southern Wisconsin. Ecol Monogr 27:325-349

10. Champion HG, Seth SK (1968) A Revised Survey of the Forest Types of India (Deli:Government of India Press), $600 \mathrm{pp}$ 
11. Charlery L, Nielsen M, Meilby H, Smith-Hall C (2016) Effects of New Roads on Environmental Resource Use in the Central Himalaya. Sustainability 8:363

12. Chaturvedi OP, Singh JS (1986) The structure and function of pine forest in central Himalaya I: Dry matter dynamics. Ann Bot 60:237-252

13. Curtis JT, Mclntosh RP (1950) The interrelations of certain analytic and synthetic phytosociological characters. Ecology 31:434-455

14. Dar GH, Bhagat RC, Khan MA (2002) Biodiversity of Kashmir Himalaya Valley Book House, Srinagar, India

15. Dar JA, Sundarapandian S (2016) Patterns of plant diversity in seven temperate forest types of Western Himalaya, India\|l. J Asia-Pac Biodivers 9:280-292

16. Dessalegn D, Beyene S, Ram N, Walley F, Tekleab S, Gala TS (2014) Effects of topography and land use on soil characteristics along the toposequence of Ele watershed in southern Ethiopia. Catena 115:47-54

17. Ferrer-Castán D, Vetaas OR (2003) Floristic variation, chorological types and diversity: Do they correspond at broad and local scales? Divers Distrib 9:221-235

18. Fisher RA, Corbet AS, Williams CB (1943) The relation between the number of species and the number of individuals in a random sample of an animal population. J Anim Ecol 12:42-58

19. Fosaa AM (2004) Biodiversity patterns of vascular plant species in mountain vegetation in the Faroe Islands. Divers Distrib 10:217-223

20. Francis AP, Currie DJ (1998) Global patterns of tree species richness in moist forests: Another look. Oikos 81:598-602

21. Gairola S, Sharma CM, Rana CS, Ghildiyal SK, Suyal S (2010) Phytodiversity (Angiosperms and Gymnosperms) in Mandal-Chopta forest of Gharwal Himalaya, Uttarakhand, India. Nat and Sci 8:1-17

22. Gautam MK, Manhas RK, Tripathi AK (2016) Patterns of diversity and regeneration in unmanaged moist deciduous forests in response to disturbance in Shiwalik Himalayas, India. J Asia Pacific Biodivers 9:144151

23. Gebrehiwot K, Dessalegn T, Woldu Z, Demissew S, Teferi E (2018) Soil organic carbon stock in Abune Yosef afroalpine and sub-afroalpine vegetation, northern Ethiopia. Ecol Process 7:6-14

24. Geneletti D, Dawa D (2009) Environmental impact assessment of mountain tourism in developing regions: A study in Ladakh, Indian Himalaya. Environ Impact Assess Rev 29:229-242

25. Gleason HA (1926) The individualistic concept of plant association. Bull Torrey Bot Club 53:7-26

26. Gotelli NJ, Colwell RK (2011) Estimating species richness Pages 39-54 in A E Magurran and B J McGill, editors Biological diversity: frontiers in measurement and assessment Oxford University Press, New York, New YolCRAF 2000

27. Grytnes JA, Vetaas OR (2002) Species richness and altitude: a comparison between null models and interpolated plant species richness along the Himalayan altitudinal gradient, Nepal. Am Nat 159:294-304

28. Hammer $\emptyset$, Harper DAT, Ryan PD (2001) PAST: paleontological statistics software package for education and data analysis. Palaeontol Electron 4(1), 9 pp

29. Hitimana JL, Kiyiapi JT, Njunge J (2004) Forest structure characteristics in disturbed and undisturbed sites of Mt Elgon moist lower montane forest, western Kenya. For Ecol Manage 194:269-291 
30. Hoy A, Katel O, Thapa P, Dendup N, Matschullat J (2016) Climatic changes and their impact on socioeconomic sectors in the Bhutan Himalayas: An implementation strategy. Reg Environ Change 16:14011415

31. Husson F, Josse J, Le S, Mazet J (2017) FactoMineR: Multivariate Exploratory Data Analysis and Data Mining R package version 136

32. Hutchins RB, Blevins RL, Hill JD, White EH (1976) The influence of soils and microclimate on vegetation of forested slopes in eastern Kentucky. Soil Sci 121:234-241

33. Irl SDH, Harter DEV, Steinbauer MJ, Puyol DG, Fernández-Palacios JM, Jentsch A, Beierkuhnlein C (2015) Climate vs topography - Spatial patterns of plant species diversity and endemism on a high-elevation island. J Ecol 103:1621-1633

34. Jacobi CM, Carmo FF (2011) Life-forms, pollination and seed dispersal syndromes in plant communities on ironstone outcrops, SE Brazil. Acta Bot Bras 25:395-412

35. Jafari SM, Zarre SH, Alavipanah SK (2013) Woody species diversity and forest structure from lowland to montane forest in Hyrcanian forest ecoregion. J Mountain Sci 10:609-620

36. Johnson EA, Miyanishi K (2007) Plant disturbance ecology: the process and response Burlington: Elsevier $\mathrm{p}$ 720

37. Kang HB, Zheng YY, Liu ST, Chai ZZ, Chang MJ, Hu YN, Li G, Wang DX (2017) Population structure and spatial pattern of predominant tree species in a pine-oak mosaic mixed forest in the Qinling Mountains, China. J Plant Interact 12:78-86

38. Karrenberg S, Kollmann J, Edwards PJ, Gurnell AM, Petts GE (2003) Patterns in woody vegetation along the active zone of a near-natural Alpine river Basic. Appl Ecol 4:157 - 166

39. Kassambara A (2017) Practical Guide To Principal Component Methods in R (Multivariate Analysis) (Volume 2), CreateSpace Independent Publishing Platform

40. Kassambara A, Mundt F (2017) Package 'factoextra' Extract and visualise the results of multivariate data analyses

41. Khamyong S, Lykke AM, Seramethakun D, Barfod AS (2004) Species composition and vegetation structure of an upper montane forest at summit of Mt Doi Inthanon, Thailand. Nord J Bot 23:83-97

42. Khera N, Kumar A, Ram J, Tewari A (2001) Plant biodiversity assessment in relation to disturbances in mid elevational forest of central Himalaya, India. Trop Ecol 42:83-95

43. Khuroo AA, Dar GH, Khan ZS, Naqshi AR (2004) Floristic diversity in the phanerogams of Langate (J and K), India. J Econ Taxon Bot 28:532-544

44. Khuroo AA, Weber E, Malik AH, Reshi ZA, Dar GH (2011) Altitudinal distribution patterns of the native and alien woody flora in Kashmir Himalaya, India Environ Res 111, 967-977

45. Körner C (2018) Concepts in empirical plant ecology. Plant Ecol Divers 11:405-428

46. Körner C, Ohsawa M, Spehn E, Berge E, Bugmann H, Groombridge B, Hamilton L, Hofer T, Ives J, Jodha N, Messerli B, Pratt J, Price M, Reasoner M, Rodgers A, Thonell J, Yoshino M (2005) Mountain systems In: Hassan R, Scholes R, Ash N (eds) Ecosystems and human well-being: current state and trends, vol 1 Millenium Ecosystem Assessment, Island Press, Washington, DC, pp 681-716

47. Krishnan MS (1982) Geology of India and Burma, 6th ed, CBS, New Delhi 
48. Kunwar RM, Sharma SP (2004) Quantitative analysis of tree species in two community forests of Dolpa district, mid-west Nepal. Him J Sci 2:23-28

49. Leak WB (1996) Long-term structural change in uneven-aged northern hardwoods. Forest Sci 42:160-165

50. Legendre P, Legendre L (1998) Numerical Ecology 2nd ed New York: Elsevier 461 p

51. Leps J, Smilaeur P (2007) Subjectively sampled vegetation data: don't throw out the baby with the bath water. Folia Geobot 42:169-178

52. Lomolino MV (2001) Elevation gradients of species-diversity: historical and prospective views. Global Ecol Biogeogr 10:3-13

53. Magurran AE (2004) Measuring biological diversity Oxford, Blackwell Science p 256

54. Mahapatra SK, Walia CS, Sindhu GS, Rana KPC, Lal T (2000) Characterisation and classification of the soils of different physiographic units in the sub-humid ecosystem of Kashmir region. J Indian Soc Soil Sci 48(3):572-577

55. Manabe T, Nishimura N, Miura M, Yamamoto S (2000) Population structure and spatial patterns for trees in a temperate old-growth evergreen broad-leaved forest in Japan. Plant Ecol 151:181-197

56. McCain CM, Grytnes JA (2010) Elevational gradients in species richness Encyclopedia of Life John Wiley \& Sons, USA

57. Menhinick EF (1964) A comparison of some species diversity indices applied to samples of field insects. Ecology 45:859-861

58. Miyadokoro T, Nishimura N, Yamamoto S (2003) Population structure and spatial patterns of major trees in a subalpine old growth coniferous forest, central Japan. Forest Ecol Manage 182:259-272

59. Mori SA, Boom BM, Carvalho AM Santos TS (1983) Southern Bahian moist forests. Bot Rev 49:155-232

60. Murcia C (1995) Edge effects in fragmented forests: implications for conservation. Trends Ecol Evol 10:5862

61. Pande PK (2001) Quantitative vegetation analysis as per aspect and altitude, and regeneration behaviour of tree species in Garhwal Himalayan forest. An For 9:39-52

62. Pandey A, Badola HK, Rai S, Rai S, Singh SP (2018) Timberline Structure and Woody Taxa Regeneration towards Treeline along Latitudinal Gradients in Khangchendzonga National Park, Eastern Himalaya PLoS ONE, 13, e207762

https://doiorg/101371/journalpone0207762

63. Parker KC (1991) Topography, Substrate, and Vegetation Patterns in the Northern Sonoran Desert. J Biogeogr 18:151-163

64. Pearson T, Walker S, Brown S (2005) Sourcebook for land use, land-use change and forestry projects Winrock International and the BioCarbon Fund of the World Bank p 57

65. Peel MC, Finlayson BL, Mcmahon TA (2007) Updated world map of the Köppen-Geiger climate classification Hydrology and Earth System Sciences Discussions, European Geosciences Union, 4, pp439473 ffhal-00298818

66. Peer T, Gruber JP, Millingard A, Hussain F (2007) Phytosociology, structure and diversity of the steppes vegetation in the mountains of Northern Pakistan. Phytocoenologia 37:1 - 65 
67. Podlaski R, Sobala T, Kocurek M (2019) Patterns of tree diameter distributions in managed and unmanaged Abies alba Mill and Fagus sylvatica L forest patches. For Ecol Manage 435:97- 105

68. Polunin A, Stainton A (1984) Flowers of the Himalaya Oxford University Press, New York and Oxford, UK

69. Pragasan A, Parthasarathy N (2010) Landscape-level tree diversity assessment in tropical forests of southern Eastern Ghats, India. Flora 205:728-737

70. R Core Team (2019) R: A language and environment for statistical computing R Foundation for Statistical Computing, Vienna, Austria URL https://wwwR-projectorg

71. Rai ID, Adhikari BS, Rawat GS, Bargali K (2012) Community structure along timberline ecotone in relation to micro-topography and disturbances in western Himalaya. Not Sci Biol 4:41-52

72. Resurrección BP, Goodrich CG, Song Y, Bastola A, Prakash A, Joshi D, Liebrand J, Shah SA (2019) In the Shadows of the Himalayan Mountains: Persistent Gender and Social Exclusion in Development The Hindu Kush Himalaya Assessment: Mountains, climate change, sustainability and people P Wester, A Mishra, A Mukherji and A B Shrestha Cham, Springer International Publishing: 491-516

73. Sariyildiz T, Anderson JM, Kucuk M (2005) Effects of tree species and topography on soil chemistry, litter quality, and decomposition in Northeast Turkey. Soil Biol Biochem 37:1695-1706

74. Schickhoff U (1995) Himalayan forest-cover changes in historical perspective A case study in the Kaghan Valley, Northern Pakistan. Mountain Res Developm 15:3-18

75. Semwal DP, Uniyal PL, Bhatt AB (2010) Structure Composition and Dominance - Diversity Relations in Three Forest Types of a Part of Kedarnath Wildlife Sanctuary, Central Himalaya, India. Not Sci Biol 2:128132

76. Shaheen H, Ullah Z, Khan SM, Harper DM (2012) Species composition and community structure of western Himalayan moist temperate forests in Kashmir. For Ecol Manage 278:138- 45

77. Sharma CM, Baduni NP, Gairola S, Ghildiyal SK, Suyal S (2010) Effects of slope aspects on forest compositions, community structures and soil properties in natural temperate forests of Garhwal Himalaya. J For Res 21:331-337

78. Sharma CM, Mishra AK, Tiwari OP, Krishan R, Rana YS (2017) Effect of altitudinal gradients on forest structure and composition on ridge tops in Garhwal Himalaya Energ Ecol Environ 2:404-417

79. Sharma CM, Tiwari OP, Rana YS, Krishan R, Mishra AK (2018) Elevational behaviour on dominancediversity, regeneration, biomass and carbon storage in ridge forests of Garhwal Himalaya, India.

For Ecol Manage 424:105-120

80. Sidhu GS, Surya JN (2014) Soils of North-Western Himalayan eco-system and their land use, constraints, productivity potentials and future strategies. Agropedology 24:1-19

81. Simpson EH (1949) Measurement of diversity. Nature 163-688

82. Singh SP, Adhikari BS, Zobel D (1994) Biomass, productivity, leaf longevity, and forest structure in the Central Himalaya. Ecol Monogr 64:401-421

83. Southwood TRE (1978) The components of diversity Pages 19-41 in L A Mound and N Walsff, editors Symposium of the Royal Entomological Society: Diversity of insect faunas Black- well Scientific, Oxford, Eng

84. Spehn EM, Liberman M, Körner C (2006) Land use change and mountain biodiversity. CRC Press Boca Raton $34: 21-25$ 
85. Spies TA (1998) Forest structure: a key to the ecosystem Northwest. Sci 72:34-39

86. Ter Braak CJF (1987) The analysis of vegetation \pm environment relationship by canonical correspondence analysis. Vegetatio 69:69-77

87. UNFCC (2015) Measurements for the Estimation of Carbon Stocks in Afforestation and Reforestation Project Activities under the Clean Development Mechanism A Field Manual

88. Valencia R, Foster RB, Villa G, Condit R, Svenning JC, Hernandez C, Romoleroux K, Losos E, Magard E, Balslev $\mathrm{H}$ (2004) Tree species distributions and local habitat variation in the Amazon: Large forest plot in eastern Ecuador. J Ecol 92:214-229

89. Wang J, Wang H, Cao Y, Bai Z, Qin Q (2016) Effects of soil and topographic factors on vegetation restoration in opencast coal mine dumps located in a loess area. Sci Rep 6:1-11

90. Xu JC, Grumbine RE, Shrestha A, Eriksson M, Yang XF, Wang Y, Wilkes A (2009) The melting Himalayas: cascading effects of climate change on water, biodiversity, and livelihoods. Conserv Biol 23:520-530

91. Yuan Z, Wang S, Ali A, Gazol A, Ruiz-Benito P, Wang X, Lin F, Ye J, Hao Z, Loreau M (2018) Aboveground carbon storage is driven by functional trait composition and stand structural attributes rather than biodiversity in temperate mixed forests recovering from disturbances. Ann For Sci 75:67

92. Zuo XA, Zhao XY, Zhao HL, Zhang TH, Li YL, Wang SK, Li WJ, Powers R (2012) Scale dependent effects of environmental factors on vegetation pattern and composition in Horqin Sandy Land, Northern China. Geoderma 173:1-9

93. Xu JC, Grumbine RE, Shrestha A, Eriksson M, Yang XF, Wang Y, Wilkes A (2009) The melting Himalayas: cascading effects of climate change on water, biodiversity, and livelihoods. Conserv Biol 23:520-530

\section{Figures}



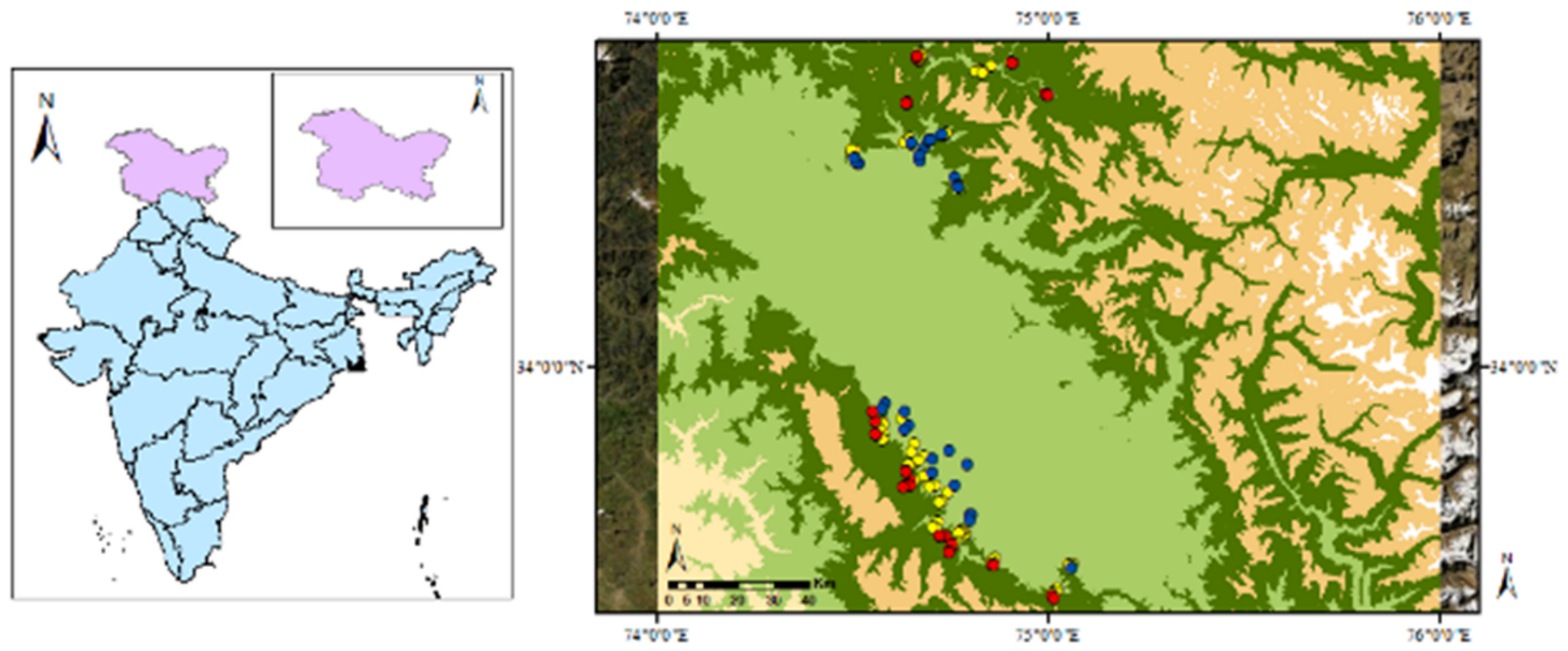

\section{Elevation a.m.s.I}

ए $353 \cdot 1,500$

$1,501 \cdot 2,600$

$2,601-3,000$

$3,801-4,900$

$4,931-6,002$

\section{Sampling points}

Forest types

- Buepinefares

- Sub alpine torest

- Moed conforcus forez:
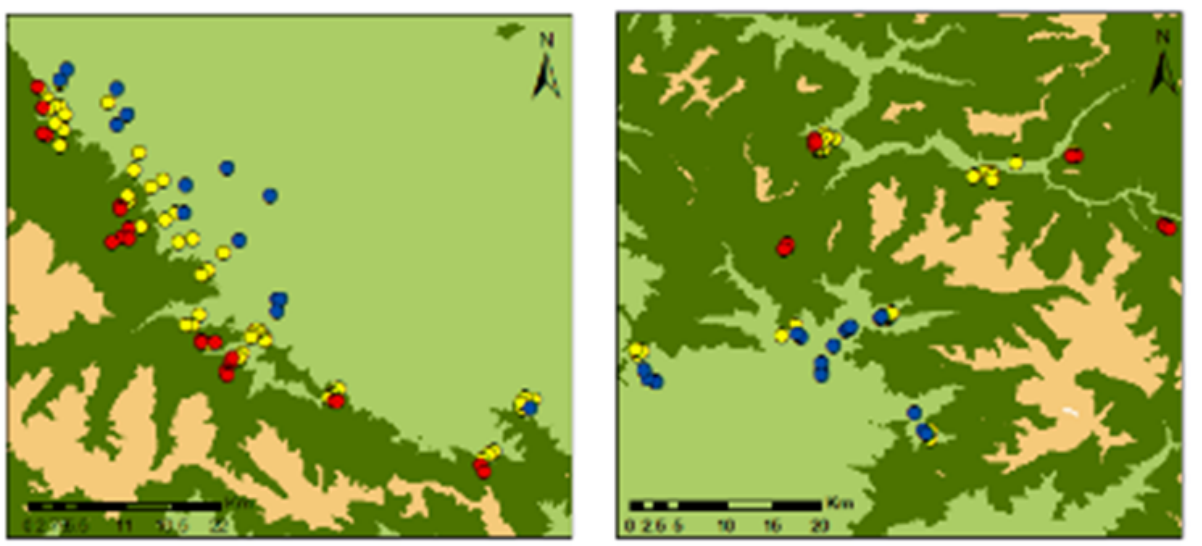

\section{Figure 1}

Geographical location of sampled plots in three forest types of temperate Kashmir Himalaya, India. The designations employed and the presentation of the material on this map do not imply the expression of any opinion whatsoever on the part of Research Square concerning the legal status of any country, territory, city or area or of its authorities, or concerning the delimitation of its frontiers or boundaries. This map has been provided by the authors.

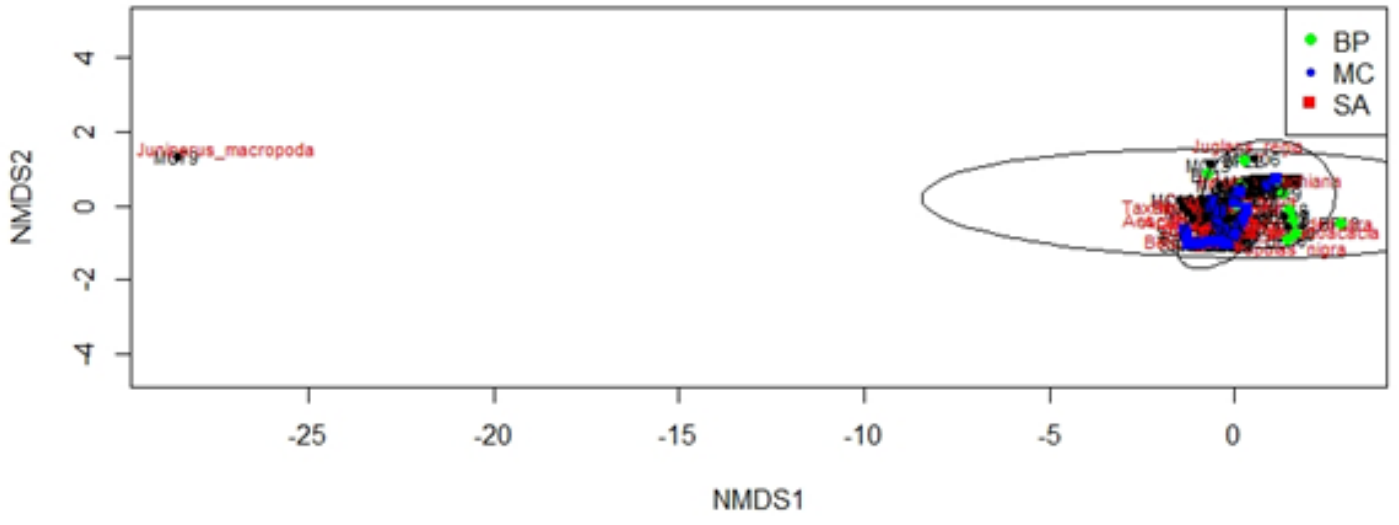

Figure 2 
Non-metric multidimensional scaling (NMDS) analysis for three temperate forest types of Kashmir Himalaya, India. Small circles indicate the site and forest type. Plus symbols represent species scores. Names of the tree species are shown in red.

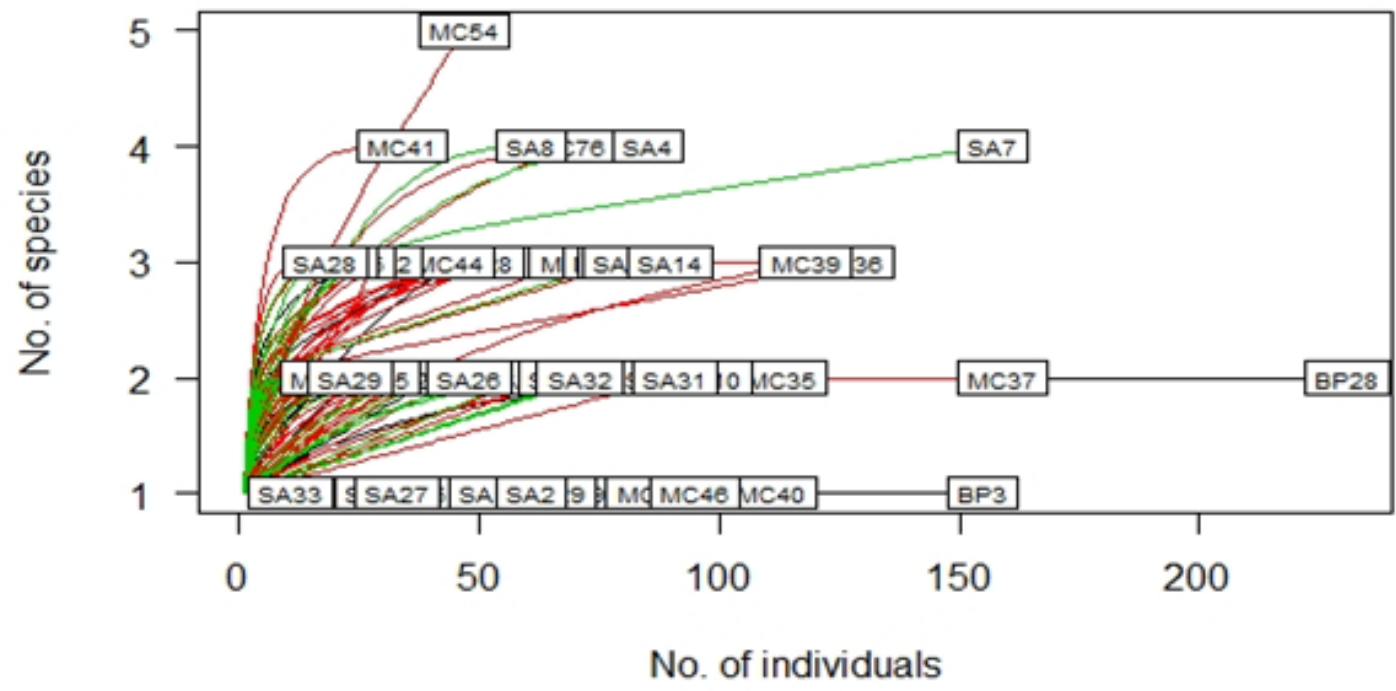

Figure 3

Rarefaction curve for 143 plots of (a) low-level blue pine (BP), (b) mixed conifer (MC) and (c) SA forests of temperate Kashmir Himalaya, India. Numeric numbers indicate the plots number within the respective forest type. 
(a) BP forest

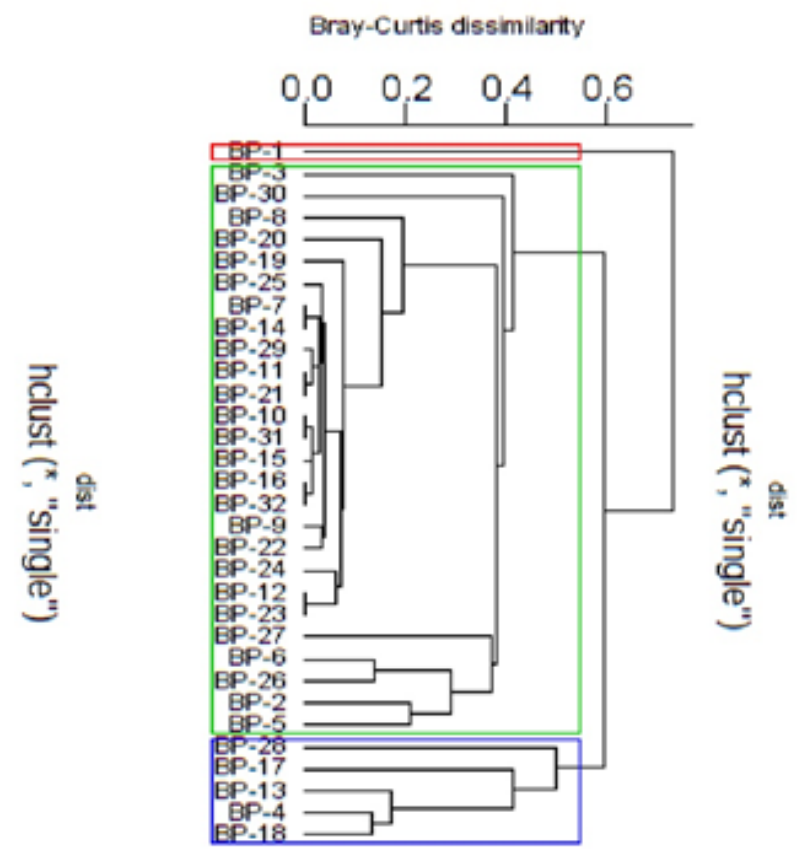

(c) SA forest

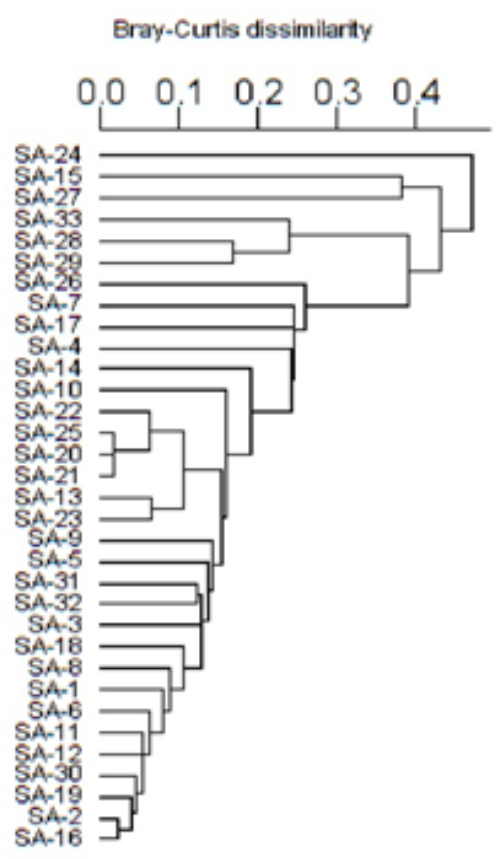

(b) MC forest

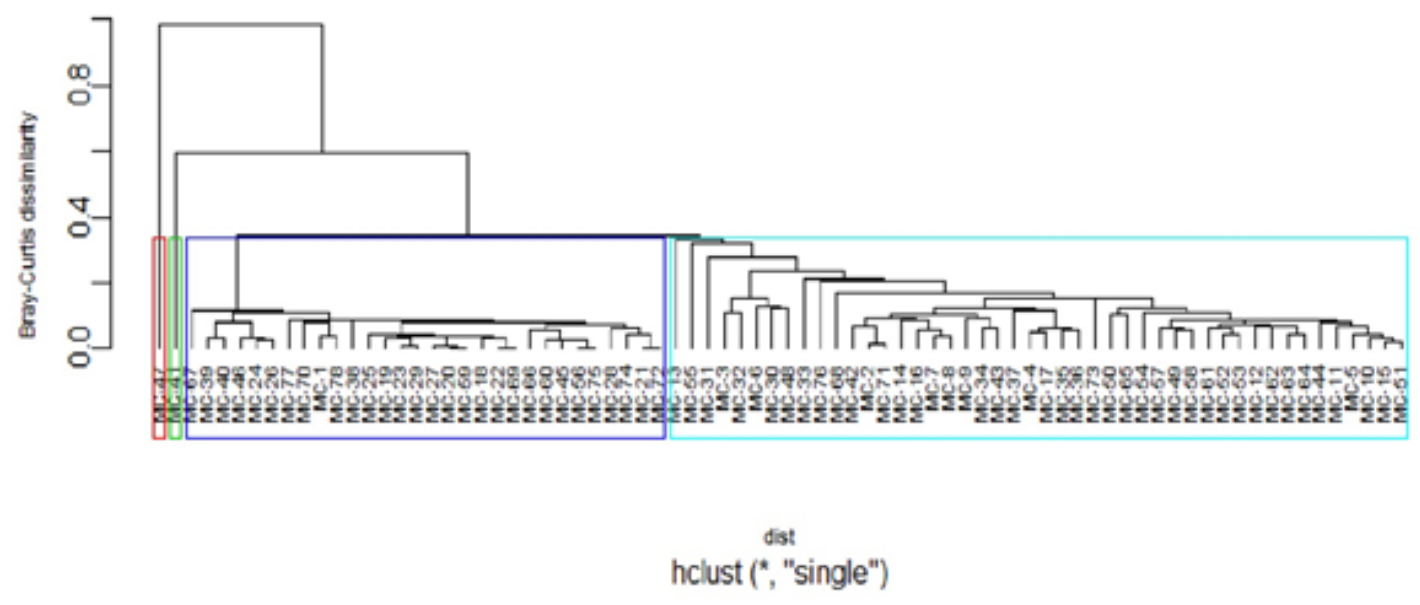

\section{Figure 4}

Dendrograms of Bray-Curtis (Single-linkage) cluster analysis based on species count and abundance in (a) lowlevel blue pine (BP), (b) mixed conifer (MC) and (c) SA forests of temperate Kashmir Himalaya, India 
(a) BP forest

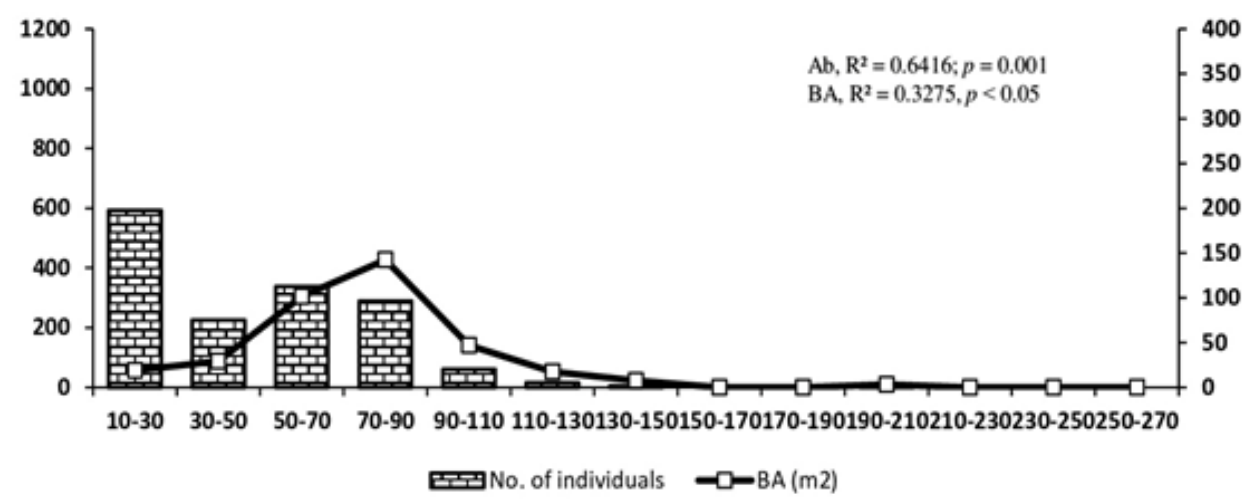

(b) MC forest

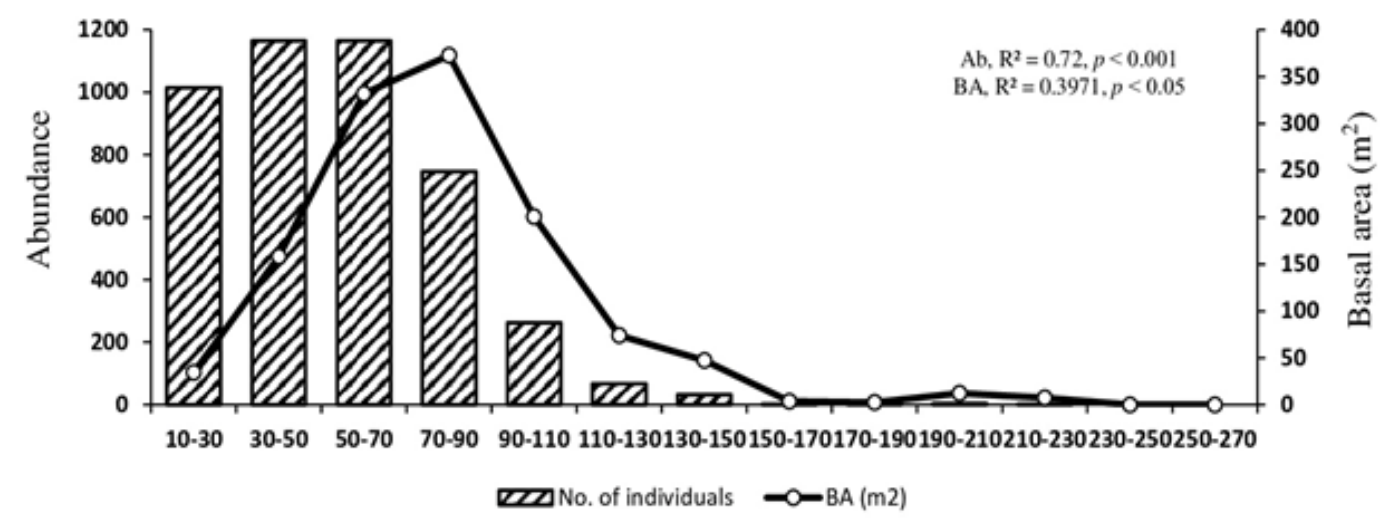

(c) SA forest

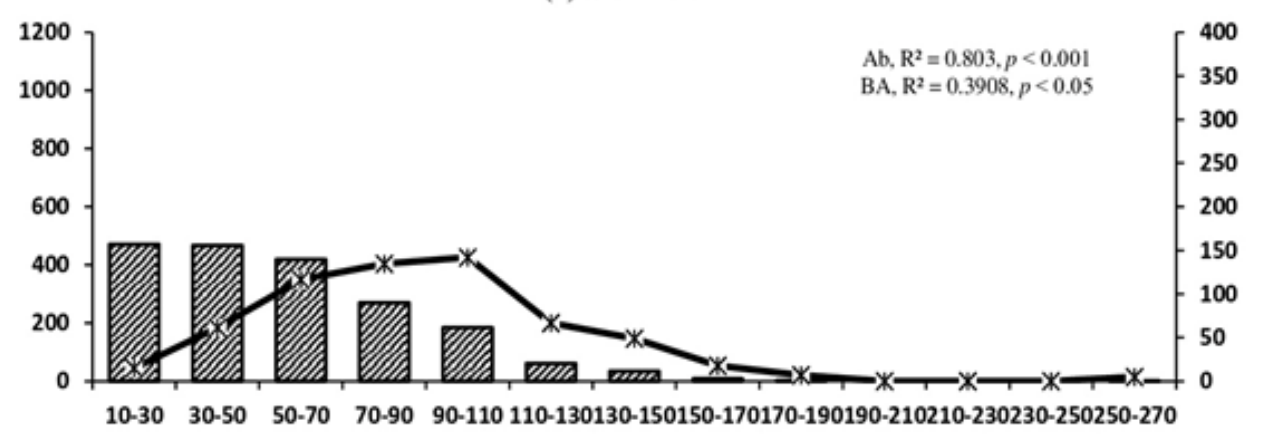

mons No. of individuals $-\mathrm{X}-\mathrm{BA}(\mathrm{m} 2)$

Diameter class $(\mathrm{cm})$

Figure 5

Abundance and BA by diameter class of tree species in (a) low-level blue pine (BP), (b) mixed conifer (MC), and (c) subalpine (SA) forests of temperate Kashmir Himalaya, India. 


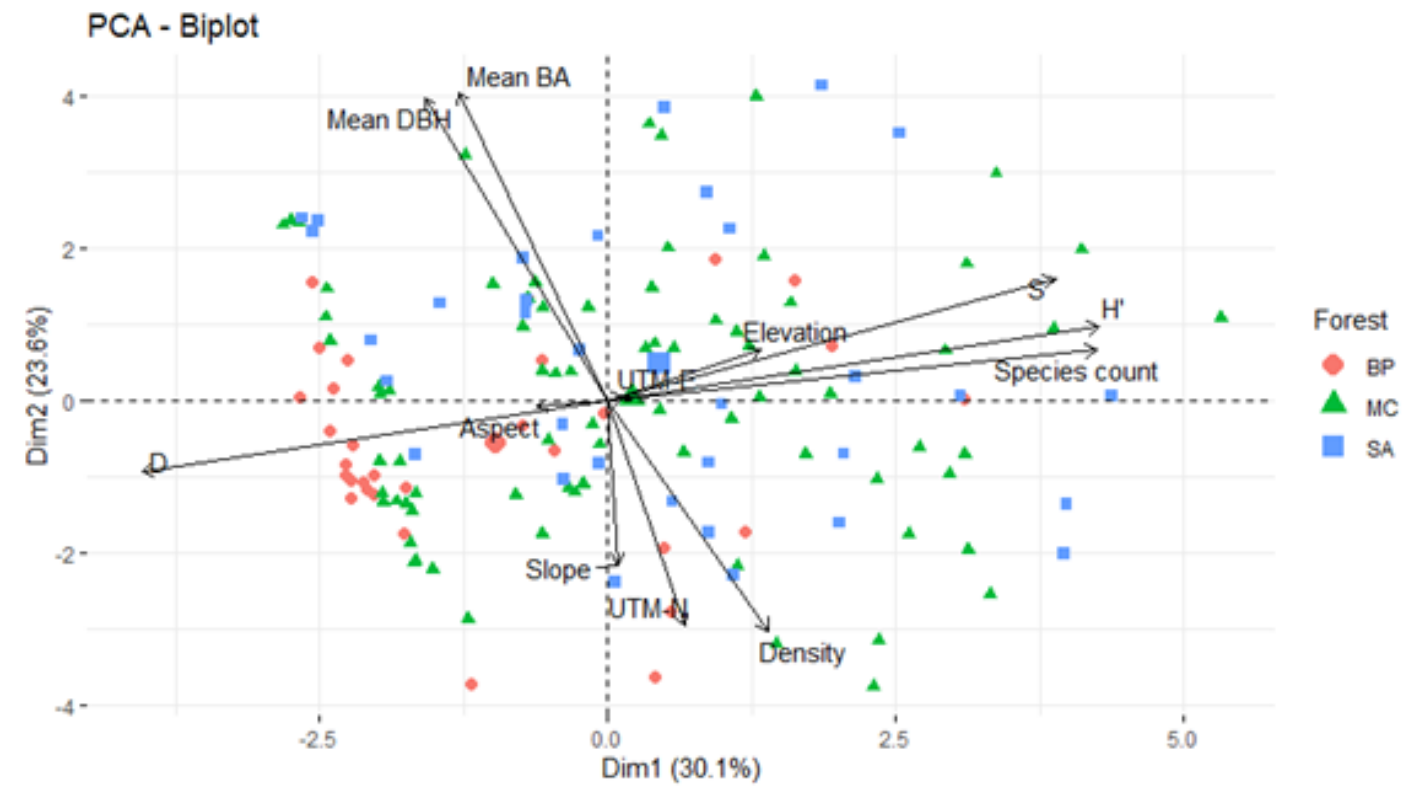

\section{Figure 6}

PCA ordination biplot diagram of 143 plots from BP, MC and SA temperate forests of Kashmir Himalaya for environmental factors, tree diversity, stand characteristics and geographical location. S, Fishers- $\mathrm{a}$ index; $\mathrm{H} \otimes$, Shannon-Wiener index; UTM-N, universal transverse mercator northing; D, Simpson index; UTM-E, universal transverse mercator easting.

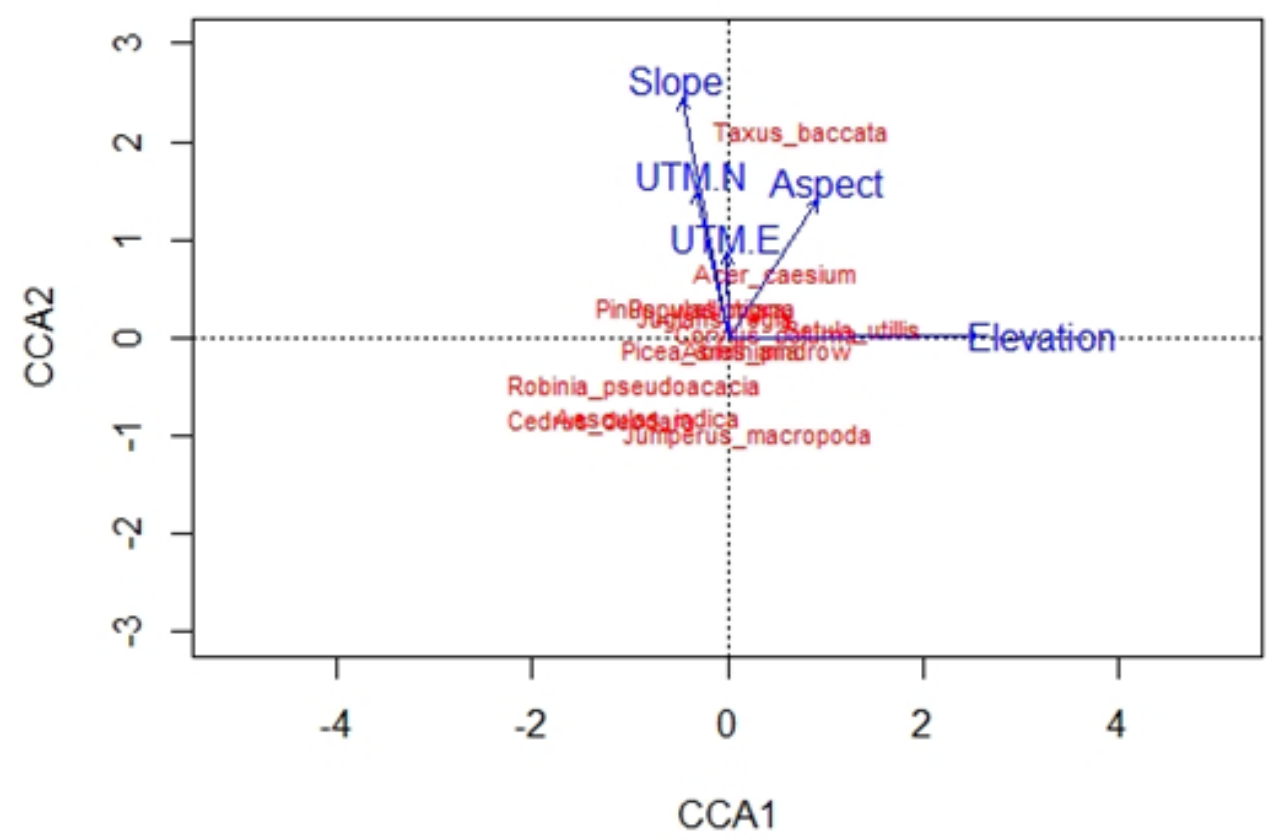

Figure 7

The plot of tree species and environmental variables (lines with arrows) from Canonical Correspondence Analysis.

\section{Supplementary Files}


This is a list of supplementary files associated with this preprint. Click to download.

- Supplementarymaterial.docx 